and partly to the Eocene system. Among the younger formations the author devotes a couple of pages to subaërial deposits, including the results of the superficial weathering of rocks and the formation of "eluvial " accumulations. The third section describes the geological structure of different traverses of the country, and localities of geological interest, while a supplement contains observations on the mineral resources of the ground reported upon.

Dr. Tietze describes in a similar methodical way the geology of East Bosnia, while Dr. Bittner takes the Herzegovina and the south-east part of Bosnia. These reports are full of interest, especially in relation to the Cretaceous and Tertiary geology of the east of Europe. To some of the questions discussed in them we may return on another occasion. Though the geologists in their rapid marches had little time to collect specimens they nevertheless found opportunity to carry off some rocks and fossils which were found of sufficient importance to deserve special description. Herr C. v. John gives a report on some crystalline rocks of the Provinces, including granite, older plagioclase rocks, younger diabases, diorites, and similar rocks from the Flysch, gabbros, serpentines, eclogites, with trachytic and andesitic lavas. Dr. Neumayr describes a series of brackish-water shells from the Tertiary formations of the Provinces.

The Geological Institute of Vienna may be congratulated on the signal success of its well-planned and admirablyconducted enterprise. Rarely has so compendious a body of detailed information in geology been so rapidly accumulated and so promptly published. Ritter von Hauer's preface is dated March I, I880--that is within a year from the time when his proposal for the Survey was laid before the Austrian Government. These few months sufficed for the field-work, for the elaboration of the reports, and for the preparation of the map and engravings. The Reports form a volume of 333 closely-printed octavo pages. The map is issued in one sheet on the scale of $\overline{5} \overline{0} \overline{0} 0 \overline{0}$, with twenty-one colours. ARCH. GEIKIE

\section{MICHEL CHASLES}

Born November 15, 1793, Died December 18, 1880.

" $\mathrm{K}$ NOW ye not that there is a prince and a great K man fallen this day?" might well have been the thought of the President Becquerel when he announced to the Academy on the 2oth ult. that Chasles was dead. To many the man who had surpassed in age Leibnitz by serenteen, Euler by eleven, Lagrange by ten, Laplace and Gauss by nine, and Newton by two years, was a "venerabile nomen," but yet a "nomen" only.

As far back as the present generation can remember Chasles has been a prince of geometers, and it has come upon many of us as a surprise to hear that he was still walking and working in our midst. A few years back a telegram was sent him from Boston conveying congratulations, and expressing the hope that the illustrious mathematician might see the close of the present century, in which event he would have surpassed the years of Pythagoras. Length of days is not always a boon, but Chasles's was a pleasant old age, and he died in harness : in such a case he might say with one of old, "nihil habeo quod incusem senectutem." "La vie de M. Chasles a été heureuse et simple; il a trouvé dans la Science, avec les plus grandes joies, une gloire qui sera immortelle, et dans la vive affection de ses amis, dans leur assiduité empressée aux réunions où il les conviait avec une grâce si aimable, dans leur respectueuse déférence en toute circonstance, la consolation de sa vieillesse."

Born at Epernon (Eure-et-Loir), he entered the École Polytechnique in 1812. At this early date he would communicate to students in the rival colleges the problems and exercises of the week, asking in return the questions proposed by their masters: "Dans cet échange organisé par le jeune lycéen, on peut croire aisément que le futur géomètre avait souvent la meilleure part." After taking his place in the defence of Paris in 1814 he passed out in engineering, but he re-entered the school in I8I5. And this is the reason: Chasles was on the point of leaving for Chartres to show his uniform and to bid farewell to his mother before going to Metz, when he was waited on by the father of one of his comrades. "Mon fils," said the father, "est le premier des élèves qui n'ont pas obtenu de place; vous avez hésité, je le sais, à accepter l'épaulette; votre refus aurait assuré à votre camarade une carrière qui lui plaît et pour laquelle j'ai fait les derniers sacrifices; il m'est impossible de les continuer pour lui en préparer une autre." Chasles made no reply : he went to Chartres; on his arrival his choice was made, and he told his mother he would stay with her. The army lost him as an officer, the world gained him as a geometer. On finally leaving the establishment, in spite of the high position he held amongst his companions, he voluntarily renounced public employment (Larousse states however: "Fut agent de change et plus tard aux affaires pour les sciènces") and went to Chartres, where he spent some ten years. $\mathrm{He}$ was working quietly however : "Toujours passionné pour la géométrie, il résolvait de beaux problèmes, comme au collège, trouvait chaque jour d'élégants théorèmes, inventait des méthodes-générales et fécondes, sans attirer l'attention des maîtres de la sciènce et sans y prétendre. 'Que de talent perdu!' disaient les plus bien-veillants, sans songer même à traiter d'égal ce jeune homme obstiné à approfondir les théories élémentaires et qui bientôt peut-être devait, par elles, s'élever bien au-dessus d'eux." Elected a Corresponding Member of the Academy in 1839 ("decorated" the same year), he was made "Professeur de Machines et de Géodésie" at the École Polytechnique, in succession to Savary in 1841 . This chair he occupied for ten years, when, in consequence of some alterations ("profondes 'et très regrettables" "), he sent in his resignation, and ever afterwards did all in his power to combat these, as he thought, dangerous reforms. His affection however continued unabated : "C'est ainsi qu'il acceptait avec tout d'empressement la présidence du Comité de la Sosiété amicale des Anciens Élèves; c'est ainsi qu'il entrait au conseil de perfectionnement, et que, tout récemment encore, malgré son grand âge, il acceptait le renouvellement de son mandat, avec le désir, disait-il, de continuer jusqu'à son dernier souffle á entretenir ce foyer de travail, d'honneur et de dévouement au pays." With the ardour which so distinguished him, M. Chasles had undertaken to write a bistory of the school; an extract from this history he recently published: "Exposé historique concernant le Cours de Machines, dans l'Enseignement de l'École Polytechnique" (see notice in NATURE, vol. xxiii. p. 75). M. Laussedat informs us that the veteran's wish is in great part attained, and that it was with great pleasure Chasles learned before bis death that the Journal de l'Ecole Polytechnique is to be revived, and that the revision of the "programmes de l'enseignement" was decided upon. In France the professorial chairs are special. ${ }^{2}$ Poinsot was, for some years, desirous that a chair should be appointed for the Modern Geometry, and in 1846 this chair was created by the Faculté des Sciences, and Chasles was elected to be the first occupant. In r 851 he was elected a Member of the Academy, and in the same year, as above stated, gave up his appointment at the Polytechnic. In 1854 he became Foreign Member of our Royal Society, in 1865 he was awarded the Copley medal, and in April, I867, he was elected the first (and for some time the only) Foreign Member of the London

I Note, p. 583, to the admirable "Discours d'Inauguration de Cours de Gé imétrie Supérieure de la Faculté des Sciences de Paris" (December 22, Superieure" (r880).

Superieure "Toutes les chaires ont un titre special." " "Rapport sur les Progrès de la Géométrie," Paris, 1870, pp. $219,376$. 
Mathematical Society. His honours of membership were numerous, and are printed on the title-pages of his works. The Pascal-Newton controversy has already been alluded to in these pages, and we willingly leave it here untouched.

" $M$. Chasles a poursuivi son œuvre sans interruption depuis sa sortie du Lycée jusqu'à l'âge de quatre-vingtsept ans. Soixante-huit années séparent la première note de l'élève Chasles, insérée dans la Correspondance sur l'École Polytechnique, du dernier mémoire présenté à l'Académie des Sciences. Tous les géomètres, sans distinction de nationalité ni d'école, se sont inclinés devant ce vénérable vieillard; tous ont admiré sa puissance d'invention, sa fécundité, que l'âge semblait rajeunir, son ardeur, et son zèle, continués jusqu'aux derniers jours."

A mere recital of the titles of $M$. Chasles' numerous papers would fill several columns. In the "Catalogue of Scientific Papers" will be found the titles of 177 , and from the slight examination we have been able to make we have little doubt that the number published since 1873 would bring the total to nearly 240 . The subjects range over curves and surfaces of the second and of any degree, geometry, mechanics (and attractions), history, and astronomy. Amongst his earliest papers are those which were translated by the present Bishop of Limerick in $184 \mathrm{I}$, under the title "Two Geometrical Memoirs on the General Properties of Cones of the Second Degree, and on the Spherical Conics." "These possess strong claims on the attention of mathematicians, whether they are considered merely as exercises of pure geometry, exhibiting its elegance and power in a remarkable degree, or as a rich and early contribution to the theory of spherical curves."

Chasles himself remarks in his Rapport ${ }^{1}$ (which perhaps furnishes the best key to his writings), "On peut s'étonner que, jusque vers la fin du premier tiers de ce siècle, on n'ait eu l'idée d'étudier ni les propriétés des cônes du second ordre qui servent à engendrer les coniques, ni celles des courbes qui tiennent sur la sphère le rang des coniques sur le plan" (p. 75).

In reply to the question, "On demande un examen philosophique des différentes méthodes employées dans la géométrie récente et particulièrement de la méthode des polaires reciproques," was written, "Mémoire de Géométrie sur deux Principes généraux de la Science, la Dualité, et l'Homographie" (January, I830, to the Académie Royale of Brussels), preceded by some historical researches. This work subsequently took the form of the famous "Aperçu historique sur l'Origine et le Developpement des Méthodes en Géométrie . . . . suivi d'un Mémoire ... sur deux Principes généraux... et l'Homographie." This work appeared in 1837 , and having become exceedingly scarce, was reprinted verbatim in 1875 , with the addition of a short preface giving a brief historical account of the book. In the Rapport (p. 8o) we are told "c'est cette troisième partie" (the memoir on Duality and Homography) "qui à donné lieu à la composition de louvrage. La théorie des figures homologiques et celle des polaires reciproques qui sont la base des beaux travaux de l'illustre Général Poncelet donnèrent une heureuse impulsion au: recherches de pure géométrie." These two methods were susceptible, he says, of generalisation, and the progress of the science demanded it. The Aperçu, which has been translated into German (except the third part) by Sohncke, is a perfect mine of geometrical facts, and is to the present day a high authority on the subject of which it treats. In some places too great reliance on Montucla (see Dr. Allman on "Greek Geometry from Thales to Euclid," p. $17 \mathrm{I}$, cf. also p. 202), and in others non-acquaintance with German (" nous éprouvons un vif regret de ne pouvoir citer ici leurs ouvrages, qui nous sont inconnues, par

\footnotetext{
I Pp. 72-126, 220-280, contain an account of the author's own contributions to geometry.
}

suite de notre ignorance de la langue dans laquelle ils sont écrits," p. 215) may slightly detract from its merits, but after all deductions it exhibits a vast amount of research and originality, and well merits the title of ouvrage classique. ${ }^{1}$

The appointment to the Chair of Modern Geometry necessitated a course (or courses) of lectures, and in 1852 these were embodied in the "Traité de Géométrie supérieure," "an elaborate and masterly treatise," which of late years has been rarely attainable, and only at a very high price. M. Chasles, hardly two months before his death, had the satisfaction of seeing a second edition, accompanying which is (pp. 547-585) the excellent "Discours d'Inauguration" (referred to above). The three fundamental principles of this work are "Anharmonic Ratio of Four Points," "Homographic Divisions," and "Involution" (Rapport, p. 220).

In I 865 appeared the first volume of the "Traite des Sections coniques, faisant suite au Traité de Géométrie supérieure." As its title indicates, constant application is made in it of the principles of pure geometry unfolded in the earlier work. It thus differs considerably not only from analytical treatises, but from geometrical treatises also: "Ces trois théories primordiales s'appliquent avec une extrème facilité à toutes les recherches concernant les sections coniques" (Rapport, pp. 266 9).

Mathematicians have long looked for a second volume, materials for which have appeared in the Comptes rendus. In the Rapport (pp. 257-266) will be found an account of the method of geometrical substitution and a definition of the elements (or characteristics) of a system of conics (Comptes rendus, 1864-7). Numerous applications are made of this remarkable theory (for further accounts the English student may refer to Dr. Salmon's " Higher Plane Curves," pp. 360, \&c., and "Conics," p. 368; see also later papers in the Comptes rendus, vol. lxxviii. ${ }^{2}$ p. 577 , \&c., vol. lxxxv. p. 362, pp. 46o-6).

We must now go back to the year 1863 , when Chasles published his "Les trois Livres de Porismes d'Euclide, rétablis pour la première Fois, d'après la Notice et les Lemmes de Pappus, et conformément au Sentiment de R. Simson, sur la Forme des Enoncés de ces Propositions." In 1838 he had contributed a paper, "Sur la Doctrine des Porismes d'Euclide," to Quetelet's Corresp. Math. x. (pp. 1-23). We must content ourselves with referring to the Rapport, pp. I 55, 233-42; the Aperçu, pp. 39, \&c. (He cites Montucla as to the profoundness of the Porisms, gives high praise to Simson, and shows that there is in Pappus's Lemmas what is in effect the projective property of the anharmonic ratio of four points). The publication of this work led to a short controversy with M. P. Bréton ("Question des Porismes-notices sur les débats de priorité auxquels a donné lieu l'ouvrage de M. Chasles sur les porismes d'Euclide," Paris, 1865; and a second part, Paris, I866). M. Chasles comments on these in the Rapport (cf. reff. above).

We turn now for a moment to the subject of attraction. "La question de l'attraction presenta-t-elle à l'auteur sous plusieurs points de vue, qui donnèrent lieu à divers mémoires et s'étendirent même au problème général de l'attraction d'un corps de forme quelconque" (Rapport, p. IOI); on p. IO3 he gives a history of Maclaurin's theorem (of which Todhunter-_" History of the Theories of Attraction," \&c., vol. i. 260, writes: "Chasles is correct"); on p. Io5 we read: "Mais il restait toujours à désirer une démonstration directe et rigoureuse du theorème de Maclaurin;" and he cites an extract from Poinsot's report on his paper (Mémoires par divers Savants, t. ix. 1846): "Ce mémoire remarquable nous offre un nouvel exemple de l'élégance et de la clarté que la géométrie peut répandre sur les questions les plus ${ }^{x}$ De Morgan says, "A work of great importance in the historical point of vicw,"

z "Considérations sur le caractère propre du principe de correspondance," "S'applique avec une très grande facilité, à une infinité de questions." 
obscures et les plus difficiles" (Comptes rendus, t. vi. I 838, pp. 808-812).

This, the first synthetic solution (of General Sabine's address on presenting the Copley Medal) was published, if we mistake not, in I 837 . M. Bertrand, in his éloge of Lamé (January 28, 1878 , Mémoires de l'Académie des Sciences), says"M. Chasles obtenait, en la transportant à la théorie si souvent étudiée de l'attraction des ellipsoïdes, des démonstrations et des résultats admirés comme un modèle d'élégance et de généralité."

We have no space left, having perhaps already dwelt too much in detail upon the complete works, to give an account of the numerous papers we referred to above. This is the less necessary as the results of many are already incorporated in the larger works. We must however just mention the important mechanical principle founded upon the proposition "quand deux polygones égaux sont placés d'une manière quelconque dans un plan, il existe toujours un point du plane qui est également distant de deux sommets homologues quelconques des deux polygones, le point est semblablement placé par rapport aux deux polygones."

The applications of this, under Poncelet's form of enunciation, are fully treated of by Richard in his "Note sur un nouveau principe de cinématique sur son emploi et sur la Théorème de M. Chasles" (Paris, 1856 ).

In the closing lines of the Rapport M. Chasles indignantly condemns the modern system which has for its supreme and immediate object des applications pratiques; and which is " caracterisée suffisamment par l'idée fatale de bifurcation." These remarks we pass over, but gladly draw attention to a wish which he strongly expresses, viz. that a defect should be remedied by the creation of two chairs, one for "Géométrie infinitésimale et analytique," and the other for "Analyse transcendante." If these chairs do not now exist, it would be a fitting compliment to his memory to establish one or both. One other wish we have which we repeat, and that is, following the fashion of the time, that a collected edition of his papers be issued, for at present they are scattered over a very wide area.

In this notice we are indebted to the funeral speeches pronounced over M. Chasles's grave (Comptes rendus, xci. No. xxv., December 20, r880) which, and M. Chasles's own remarks, we have freely cited in their original language, thereby securing conciseness of expression.

We must however linger no longer by the grave, but turn to the "living present," after repeating M. Dumas's last words, "Adieu, Chasles, adieu!" R. TUCKER

\section{PROF. HUXLEY ON EVOLUTION ${ }^{\mathrm{r}}$}

II.

IF all the Mammalia are the results of a process of 1 evolution analogous to that which has taken place in degrees of that process, then a natural classification will arrange them, in the first instance, according to the place which they occupy in the scale of evolution of the mammalian type, or the particular rung of the "scala mammalium " on which they stand. The determination of the position thus occupied by any group may, I think, be effected by the deductive application of the laws of evolution. That is to say, those groups which approach the non-mammalian Vertebrata most closely, present least inequality of development, least suppression, and least coalescence of the fundamental parts of the type, must belong to earlier stages of evolution; while those which exhibit the contrary characters must appertain to later stages.

I Continued from p. 204. By the courtesy of the Secretary of the Zoolological Society we are able to give the remainder of the paper "On the Application of the Laws of Evolution to the Arrangement of the Vertebrata,
and more particularly of the Mammalia," by Prof. T. H. Huxley, F.R.S.
Judged from this point of view, there can be no doubt that the Monotremes embody that type of structure which constitutes the earliest stage of mammalian organisation :- -

r. The mammary glands are devoid of teats; and thus the essential feature of the mammal could hardly be presented under a simpler form.

2. There is a complete and deep cloaca, as in Vertebrata lower in the scale.

3. The openings of the ureters are hypocystic-that is to say, they open, not into the bladder of these animals, but behind it, into the dorsal wall of the genito-urinary passage. As this answers to the neck of the allantois, the ureters of the Monotremes retain their primitive embryonic position.

4. There is no vagina apart from the genito-urinary passage, and the oviducts are not differentiated into distinct uterine and Fallopian regions.

5. The penis and the clitoris are attached to the ventral wall of the cloaca.

6. The epiphyses of the vertebræ are but slightly, or not at all developed. ${ }^{1}$

7. The malleus is relatively very large, and the "processus gracilis," which is singularly long and strong, passes between the tympanic and the periotic bones to the pterygoid, with which it is firmly united. Thus the palato-pterygoid apparatus is directly connected by a "suspensorium" with the periotic, as in the Amphibia and Sauropsida. As in these, the representative of the incus is extremely small and that of the stapes columelliform.

8. The coracoid is complete, distinct, and articulates with the sternum.

9. The hip-girdle is provided with large epipubes, and the iliac axis is inclined at a large angle to the sacral axis.

ro. The corpus callosum is very small.

II. There appears to be no allantoic placenta, though, from the obvious remains of the ductus arteriosus and of the hypogastric arteries, there can be little doubt that the fœtus has a large respiratory allantois. It is quite possible that, with a large umbilical sac, there may be an imperfect "umbilical" placentation.

But, while the Ornithorhynchus and the Echidna are thus the representatives of the lowest stage of the evolution of the Mammalia, I conceive-it to be equally unquestionable that, as Haeckel has already suggested, they are greatly modified forms of that stage-Echidna, on the whole, representing a greater, and Ornithorhynchus a less, departure from the general type. The absence of true teeth in both genera is an obvious sign of extreme modification. The long tongue, extraordinary external auditory passages, and relatively large convoluted brain of Echidna, and the cheek-pouches and horny mouth-plates of Ornithorhynchus, are other indications of the same kind.

Hence, the primary mammals which were less modified, and the existence of which is necessarily postulated in the conception of the evolution of the group, cannot, without risk of confusion, be called Monotremata or Ornithodelphia, since in all probability they were as widely different from Ornithorhynchus and Echidna as the Insectivora are from the Edentata, or the Ungulata from Rhytina. It will therefore be convenient to have a distinct name-Prototheria - for the group which includes these, at present, hypothetical embodiments of that lowest stage of the mammalian type, of which the existing Monotremes are the only known representatives.

A similar reasoning applies to the Marsupialia. In their essential and fundamental characters they occupy an

${ }^{x}$ Dr. Albrecht ("Die Epiphysen und die Amphiomphalie der Säugethierwirbel-körper:" Zoologischer Anzeiger, 1879, No. 18), while admitting that Echidna has no epiphyses, describes epiphyses of an incomplete characte between the posterior twelve caudal vertebræ of Ornithorhynchus. So far as I am aware, the memoir of which Dr. Albrecht has given a preliminary notice, has not yet been published. I content myself therefore with remarking that my own recent observations are in harmony with Dr. Albrecht's statement. 